\title{
Diagnosis Kesulitan Belajar Mahasiswa Dalam Memahami Konsep Momentum
}

\author{
Saeful Karim ${ }^{1, a)}$, Duden Saepuzaman ${ }^{1, b)}$, S. P. Sriyansyah ${ }^{2, c)}$ \\ ${ }^{1}$ Departemen Pendidikan Fisika, FPMIPA, Universitas Pendidikan Indonesia, Bandung, 40154 \\ ${ }^{2}$ Sekolah Pascasarjana, Universitas Pendidikan Indonesia, Bandung, Indonesia
}

Email: a)saefulkarimsk@gmail.com, b)dsaepuzaman@upi.edu, c)syaktiperdana@gmail.com

\begin{abstract}
This descriptive study was motivated by the achievement of students' understanding of the concept of momentum that was still not as expected. The purpose of this study was to determine students' conceptual understanding and reveal students' learning difficulties on the concept of momentum in order to plan appropriate learning program. The research subject was 41 students who attend introductory physics course at LPTK in West Java. Data collection tool in the form of multiple-choice diagnostic tests, Momentum Conceptual Survey. Based on the results of diagnostic tests, students had difficulties as follows. First, students found it difficult to apply the concept of momentum in various physics context, especially new physics context that stated qualitatively. Second, students considered the concept of momentum is equal to the concept of energy, namely as a scalar quantity. Third, they found it difficult to apply conservation law of linear momentum in new physics context. Students were too focused on the velocity in solving momentum problems. Fourth, there was fallacy related to the applicability of the conservation law of momentum for objects, not only for the system. Fifth, students were unable to describe momentum, and impulse that expressed in vector representation.
\end{abstract}

Keywords: diagnosis of learning difficulties, the concept of momentum

\begin{abstract}
Abstrak
Penelitian ini dilatarbelakangi oleh pencapaian penguasaan konsep momentum mahasiswa yang masih belum sesuai harapan. Tujuan penelitian ini adalah untuk mengetahui pemahaman konsep mahasiswa dan mengungkap kesulitan yang dialami mahasiswa pada konsep momentum dalam rangka merencanakan program pembelajaran yang tepat. Metode yang digunakan adalah deskriptif analitik dengan sampel sebanyak 41 mahasiswa yang mengikuti perkuliahan Fisika Dasar pada salah satu LPTK di Jawa Barat. Alat pengumpul data berupa tes diagnostik Momentum Conceptual Survey yang berbentuk pillihan ganda. Berdasarkan hasil tes diagnostik, diketahui bahwa mahasiswa mengalami kesulitan sebagai berikut. Pertama, mahasiswa kesulitan dalam menerapkan konsep momentum dalam berbagai situasi fisika, terutama situasi fisika baru atau yang dinyatakan dalam bentuk deskriptif. Mahasiswa masih sering menyelesaikan persoalan momentum yang dinyatakan secara deskriptif, tidak dalam bentuk angka, tanpa menggunakan prinsip Fisika yang telah dipelajari. Kedua, mahasiswa memandang konsep momentum sama dengan konsep energi, yaitu sebagai besaran skalar. Ketiga, mahasiswa kesulitan menerapkan hukum kekealan momentum dalam situasi fisika baru, terutama dalam konteks soal yang memiliki massayang berubah. Mahasiswa terlalu fokus pada aspek kecepatan dalam penyelesaian persoalan momentum. Keempat, adanya
\end{abstract}


kekeliruan berpikir terkait keberlakuan hukum kekekalan momentum untuk benda, bukan hanya untuk sistem. Kelima, mahasiswa kesulitan dalam mendeskripsikan momentum, perubahan momentum, dan impuls yang dinyatakan dalam representasi vektor.

Kata-kata kunci: diagnosis kesulitan, konsep momentum

\section{PENDAHULUAN}

Dalam setiap perkuliahan, dosen dan mahasiswasenantiasa mengharapkan agar tujuan perkuliahan yang telah ditetapkan tercapai.Dosenterkadang telah merasa total dalam membelajarkan mahasiswa, tetapi kenyataannya ditinjau dari hasil tes atau ujian, banyak mahasiswa yang tidak dapat mencapai hasil belajar yang diharapkan. Selain itu, selama proses perkuliahan, kadang dosen kesulitan dalam menentukan seberapa banyak mahasiswa yang benar-benar telah mencapai hasil belajar dan seberapa banyak mahasiswa yang masih mengalami kesulitan belajar, apalagi jika dalam perkuliahan kelas besar, misalnya 130 mahasiswa dalam satu kelas.

Kesulitan yang dialami mahasiswa hendaknya dideteksi oleh dosen sedini mungkin agar segera dapat direncanakan program pembelajaran (termasuk penguatan materi) yang sesuai.Kesulitan belajar yang dialami mahasiswa tentu bervariasi, baik macammaupun penyebabnya. Menurut Surya dan Amin (1984), terdapat gejala yang mengindikasikan mahasiswa mengalami kesulitan belajar, beberapa diantaranya yaitu: menunjukkanperolehan hasil belajar yang rendah,tidak seimbangnya hasil yang dicapai dengan usaha yang telah dilakukan dan lambat dalam melakukan tugas kegiatan belajar.Berdasarkanindikasi tersebut, makacara yang efektif untuk mendeteksi kesulitan belajar mahasiswa, apalagi dalam sebuah perkuliahan kelas besar, yaitu denganmelakukan pengukuran hasil belajar, misalnya dengan menggunakan tes diagnostik.

Metode serupa juga digunakan oleh Physics Education Research Group (PER) yang dipelopori oleh Lilian C. Mc Dermott, hampir selama dua dekade, untuk menyelidiki pemahaman konsep dan kesulitan konseptual yang dialami oleh mahasiswa (Heron dan Mc Dermott, 1998). Dua metode yang digunakan oleh PER, yaitu wawancara demonstrasi individu (individual demons-tration interview) dan studi deskriptif melalui tes tertulis (written tests) (Mc Dermott, 2013). Pengamatan dan interaksi dengan mahasiswa di dalam kelas juga memberi informasi mendalam tentang bagaimana mahasiswa belajar dengan baik.

Terkait dengan kesulitan mahasiswa, berdasarkan pengalaman penulis selama dua tahun terakhir sebagai tim pengampu mata kuliah Fisika Dasar, pencapaian hasil belajar mahasiswa untuk perkuliahan Fisika Dasar 1 ternyata belum sesuai dengan yang diharapkan. Secara umum, rata-rata nilai Tes Unit 2 Fisika Dasar I yang diperoleh mahasiswa tingkat 1 semeseter 2 yaitu 41 (skala 1100) pada tahun ajaran 2012/2013 dan 46 pada tahun ajaran 2013/2014. Analisis lebih lanjut terhadap jawaban mahasiswa ditemukan bahwa sebagian besar (sekitar 65\%) kesulitan mahasiswa terletak pada konsep momentum.

Konsep momentum merupakan konsep yang penting dalam fisika sama halnya dengan konsep energi (Van Heuvelen,1991). Kesulitan yang dialami mahasiswa pada konsep momentum telah dilaporkan oleh beberapa hasil penelitian terdahulu. Close dan Heron (2010) melaporkan bahwa mahasiswa cenderung meninjau hukum kekekalan momentum sebagai hukum kekekalan besaran skalar, bukan sebagai vektor. Penelitian Graham dan Berry (1996) terhadap lebih dari 500 siswa di Inggris (usia 17-18) juga menyimpulkan bahwa sebagian besar siswa memahami momentum sebagai besaran skalar. Demikian juga halnya, laporan penelitian Lawson dan McDermott (1987) dan Pride et. al.(1998). Selain memahami momentum sebagai besaran skalar, mahasiswa juga kesulitan dalam menghubungkan persamaan matematis momentum pada kasus tumbukan dengan fenomena gerak yang mereka amati.

Kenyataan bahwa mahasiswa mengalami kesulitan pada konsep momentum, bertolakbelakang dengan pengamatan selama pembelajaran. Selama proses perkuliahan, hasil pengamatan langsung menunjukkan bahwa mahasiswa cukup paham dengan konsep momentum yang disampaikan. Sebagian besar mahasiswa tampak bisa mengikuti perkuliahan dan menerima materi yang sedang dipelajari.Hal ini dibuktikan dengan apabila dosen mengajukan pertanyaan konseptual untuk mengecek pemahaman mahasiswa saat itu, mahasiswa bisa menjawab. 
Akan tetapi, indikasi kesulitan mahasiswa mulai nampak dalam kegiatan responsi.Selain untuk menguatkan konsep, kegiatan responsi memang sengaja diperuntukkan untuk merespon kesulitan mahasiswa dalam memahami materi Fisika Dasar yang telah dipelajari sebelumnya. Tetapi, kadang mahasiswa kurang mampu menyatakan letak kesulitan yang dialami secara eksplisit dan spesifik.Bahkan tak jarang ketika dosen meminta mahasiswa untuk menyatakan kesulitan yang dialami, mahasiswa tidak menjawab.Tentu saja respon mahasiswa ini mengindikasikan dua kemungkinan, apakah mereka sudah paham atau belum. Hal inilah yang mesti ditelusuri lebih jauh oleh dosen.

Salah satu upaya yang bisa dilakukan untuk mengetahui secara pasti kesulitan mahasiswa adalah dengan memberikan tes diagnostik.Mengidentifikasi kesulitan belajar dengan tes diagnostik sebenarnya merupakan langkah awal saja.Langkah berikutnya adalah melacak penyebab kesulitan belajar mahasiswa tersebut, kemudian menentukan penanganan yang tepat. Menurut Nitko, seperti yang dikutip dalam Mulyono (2003) tes diagnostik mempunyai dua fungsi, yaitu mengetahui target belajar yang belum dicapai oleh mahasiswa dan mengidentifikasi penyebab mengapa mahasiswatidak mencapai target tersebut. Selain itu, tes diagnostik utamanya juga bertujuan untuk mengidentifikasi kesulitan belajar yang menetap atau berulang dan untuk merumuskan rencana pengajaran yang tepat (Gronlund, 1985).

Berdasarkan paparan tersebut,penelitian ini dilakukan untuk mengetahui kesulitan mahasiswa dalam memahami konsep momentum melalui tes diagnostik. Hal ini dilakukan dalam rangka untuk menentukan rancangan pembelajaran yang tepat, terutama dalam kegiatan responsi. Dengan demikian, kegiatan responsi benar-benar sebagai upaya untuk menguatkan pemahaman konsep mahasiswa, sekaligus merespon dan membantu mengatasi kesulitan mahasiswa sebelum menghadapi ujian.

\section{METODE}

Penelitian ini merupakan penelitian deskriptif analitik yang menggambarkan kesulitan konseptual yang dialami mahasiswa pada konsep momentum.Subjek penelitian sebanyak 41 mahasiswa pendidikan Fisika angkatan 2014/2015 yang mengambil mata kuliah Fisika Dasar I di salah satu LPTK Bandung.

Pengumpulan data menggunakaninstrumen yang dikonstrukdari tes standarberbentuk pilihan ganda sebanyak 15 item soal. Sebanyak 13 item soal diambil dari tes Momentum Conceptual Survey (Singh, 2003), sedangkan 2 item soal diambil dari tes Mechanics Baseline Test (Hestenes, D, 1992). Konsep yang terdapat dalam tesmeliputi definisi momemtum, hukum kekekalan momentum, aplikasi hukum kekekalan momentum, dan teorema impuls-momentum.

Tes diberikan setelah mahasiswa mengikuti pembelajaran konsepmomentum.Tujuannya hanya untuk melihat bagaimana konsepsi dan sejauhmana pemahaman mahasiswa setelah mengikuti pembelajaran momentum.Hal ini sangat diperlukan sebagai pijakan untuk kegiatan responsi.

Untuk melihat gambaran pemahaman konsepmahasiswa,tiap item soal tes diberi skor 1 jika dijawab benar dan skor 0 jika dijawab salah. Analisis data didasarkan pada rata-rata perolehan skor mahasiswa untuk tiap subkonsep.

\section{HASIL DAN PEMBAHASAN}

Secara umum, jumlah mahasiswa yang menjawab benar (B) dan salah (S) untuk tiap item soal dinyatakan dalam Tabel 1. Berdasarkan data pada Tabel 1, mahasiswa banyak menjawab salah pada konsep hukum kekekalan momentum, terutama soal \#11.Adapun kesulitan mahasiswa pada tiap konsep berturut-turut: definisi momentum (14\%), hukum kekekalan momentum (35\%), dan teorema impuls-momentum (24\%). 
TABEL 1. Rekapitulasi jumlah mahasiswa yang menjawab benar (B) dan salah (S)

\begin{tabular}{|c|c|c|c|c|}
\hline \multirow[t]{2}{*}{ Konsep } & \multirow[t]{2}{*}{ Subkonsep } & \multirow{2}{*}{$\begin{array}{l}\text { No. } \\
\text { soal }\end{array}$} & \multicolumn{2}{|c|}{$\begin{array}{l}\text { Jumlah } \\
\text { Mahasiswa }\end{array}$} \\
\hline & & & B & $\mathbf{S}$ \\
\hline \multirow{3}{*}{$\begin{array}{l}\text { Definisi } \\
\text { momentum }\end{array}$} & Besar momentum (kuantitatif) & \#3 & 38 & 3 \\
\hline & Penentuan momentum dan energi kinetik & $\# 6$ & 39 & 2 \\
\hline & $\begin{array}{l}\text { Penentuan perubahan momentum secara grafik } \\
\text { (vektor) }\end{array}$ & \#14 & 29 & 12 \\
\hline \multirow{6}{*}{$\begin{array}{c}\text { Hukum } \\
\text { kekekalan } \\
\text { momentum }\end{array}$} & \multirow{3}{*}{$\begin{array}{l}\text { Penerapan hukum kekekalan momentum secara } \\
\text { umum }\end{array}$} & $\# 4$ & 24 & 17 \\
\hline & & \#8 & 40 & 1 \\
\hline & & \#11 & 11 & 30 \\
\hline & \multirow{2}{*}{ Tumbukan lenting sempurna } & $\# 1$ & 25 & 16 \\
\hline & & $\# 5$ & 28 & 13 \\
\hline & Tumbukan tidak lenting & $\# 2$ & 20 & 21 \\
\hline \multirow{5}{*}{$\begin{array}{l}\text { Teorema } \\
\text { impuls- } \\
\text { momentum }\end{array}$} & \multirow{3}{*}{ Kaitan impuls dengan momentum } & $\# 9$ & 41 & \\
\hline & & 9 & 41 & 0 \\
\hline & & $\# 10$ & 30 & 11 \\
\hline & \multirow[t]{2}{*}{ Aplikasi teorema impuls-momentum } & \#12 & 28 & 13 \\
\hline & & \#13 & 27 & 14 \\
\hline
\end{tabular}

\section{Analisis Kesulitan Mahasiswa}

Analisis lebih lanjut terhadap kesulitan mahasiswa dalam menjawab soal momentum yang diujikan diperoleh dari catatan mahasiswa dalam lembar jawaban danwawancara terhadap beberapa mahasiswa.

Soal yang terkait definisi momentum. Soal \#3, \#6 dan \#14 akan bisa dijawab jika mahasiswa memahami definisi momentum sebagai besaran vektor baik besar maupun arahnya yang dinyatakan secara grafik. Pada soal \#3, masih terdapat mahasiswa yang hanya berfokus pada aspek besar kecepatan saja, tanpa mempertimbangkan aspek massa, dalam menentukan besar momentum.

Alasan mahasiswa menjawab salah pada soal \#6 adalah mahasiswa meninjau momentum dari besarnya saja, bukan meninjau momentum sebagai besaran vektor. Hal ini berdampak pada penjumlahan momentum untuk mendapatkan momentum total sistem yang dijumlahkan secara aljabar biasa, padahal seharusnya diresultankan secara vektor. Namun demikian, hanya terdapat beberapa orang mahasiswa saja yang salah di soal \#3 dan \#6. Kesalahan yang dialami mahasiswa ini, sama dengan yang telah dilaporkan sebelumnya, tapi dalam penelitian ini, banyak mahasiswa yang salah menjawab konsep ini lebih sedikit.

Untuk soal \#14, kesulitan mahasiswa dalam menentukan perubahan momentum secara grafis lebih disebabkan karena lemahnya pemahaman mahasiswa dalam pengetahuan penjumlahan vector, bila dibanding dengan pemahaman momentum sebagai besaran skalar. Kesalahan yang paling banyak dilakukan mahasiswa adalah dengan meninjau perubahan momentum sebagai penjumlahan antara vektor momentum awal dan akhir, padahal seharusnya adalah penjumlahan antara vektor momentum akhir dengan negatif vektor momentum awal. Hal ini menunjukkan bahwa konsep momentum sebagai besaran vektor dan metode penjumlahan vektor masih menjadi kesulitan yang dialami mahasiswa, seperti halnya yang dilaporkan penelitian terdahulu.

Soal yang terkait hukum kekekalan momentum. Secara umum, soal terkait hukum kekekalan momentum dibagi menjadi tiga subkonsep, yaitupenerapan hukum kekekalan momentum secara umum (\#4, \#8 dan \#11),tumbukan lenting sempurna (\#1 dan \#5) dantumbukan tidak lenting (\# 2 dan \#7). Pada soal \#4, kesulitan mahasiswa terdapat pada anggapan bahwa hukum kekekalan energi kinetik berlaku karena tumbukan bersifat lenting sempurna. Dalam soal memang tertulis, tanpa gesekan, tetapi bukan berarti energi kinetik tidak ada yang hilang akibat tidak adanya gesekan. Faktanya, energi kinetik bisa berkurang karena ada energi bunyi atau energi lain yang digunakan untuk memutuskan ikatan antar molekul penyusun zat. Konsep ini yang perlu untuk ditekankan kembali. 
Untuk soal \#8, mahasiswa tidak mengalami kesulitan karena kasus/konteks soal telah dikenaldan sering ditemui dalam soal problem solving oleh mahasiswa.Adapun soal \#11, sebanyak 30 dari 41 mahasiswa menjawab salah. Mahasiswa mengerti bahwa jenis tumbukan yang disajikan dalam soal adalah inelastik (tidak elastik), tetapi kecenderung mahasiswa yang salah menjawab pilihan (A) dan (C). Untuk pilihan (A), mahasiswa beralasan bahwa hujan yang jatuh vertikal tidak memberikan pengaruh pada laju kereta, sedangkan untuk pilihan (C), menurut mahasiswa momentum dalam arah horizontal bersifat kekal, karena air hujan tidak mempunyai komponen momentum dalam arah horizontal, sehingga kecepatan kereta dalam arah horizontal tidak berubah. Dengan kata lain, dapat dikatakan bahwa alasan yang digunakan mahasiswa untuk menjawab soal \#11 lebih berfokus pada kecepatan, bukan berfokuspada momentum. Secara matematis, hukum II Newton kaitannya dengan konsep momentum dapat ditulis:

$$
\sum F=\frac{d P}{d t}=\frac{d(m v)}{d t}
$$

dimana untuk kasus soal \#11, resultan gaya yang bekerja sama dengan nol, sehingga momentum kekal. Tapi, bukan berarti kecepatan konstan, karena disini massa tidak konstan. Ketika massa sistem bertambah, dengan tambahan air hujan, kecepatan kereta berkurang, dan momentum kekal.

Soal \#1 dan \#5 tentang tumbukan lenting sempurna.Kecenderungan alasan mahasiswa adalah jika tumbukan lenting sempurna, maka besar momentum sistem dan momentum masing-masing benda kekal. Padahal, yang bersifat kekal adalah momentum sistem, baik besar maupun arah.Sementara itu, pada soal \#2 tentang aplikasi jenis tumbukan tidak lenting, mahasiswa banyak yang hanya menduga dan bernalar secara kualitatif/deskriptif, sehingga masih berupa prediksi. Padahal, untuk kondisi soal \#2, bisa dijawab atau dibuktikan secara kuantitatif.Adapun untuk soal \#7, mahasiswa yang salah, kembali memandang momentum sebagai skalar.

Soal yang terkait teorema impuls-momentum.Kaitan antara impuls dengan momentum diukur dengan soal \#9 dan \#15. Untuk soal \#9, semua mahasiswa dapat menjawab benar.Sedangkan soal \#15, terdapat 15 mahasiswa yang menjawab salah.Mahasiswa masih kesulitan untuk menentukan impuls dan momentumyang disajikan secara vektor, padahal mahasiswa mengetahui keterkaitan antara impuls dengan momentum.Pada bagian ini, mahasiswa dominan mengalami kesulitan pada bagian aplikasi teorema impuls-momentum yang diukur dengan soal \#10 (26\%), \#12 (31 \%), dan \#13 (34\%).Secara umum, kesulitan yang dihadapi mahasiswa karena tidak menggunakan prinsip fisika, mahasiswa terlalu berfokus pada penalaran dan logika tanpa melakukan perhitungan secara kuantitatif menggunakan prinsip fisika.Padahal sebenarnya meskipun soalnya bersifat deskriptif, tetapi untuk menjawabnya bisa dilakukan secara analisis kuantitatif menggunakan teorema impulsmomentum.

Adapun secara keseluruhan, gambaran kesulitan yang dialami mahasiswa dalam penelitian ini, sejalan dengan hasil penelitian sebelumnya, yaitu mahasiswa cenderung menganggap momentum sebagai besaran skalar, bukan besaran vektor, dan masih mengalami kesulitan menghubungkan dan/atau memahami arti fisis persamaan matematis kaitannya dengan fenomena gerak yang diamati.

\section{PENUTUP}

Berdasarkan pembahasan yang telah disajikan, dapat disimpulkan beberapa temuan terkait kesulitan belajar mahasiswa dalam memahami konsep momentum. Pertama,mahasiswa kesulitan dalam menerapkan konsep momentum dalam berbagai situasi fisika, terutama situasi fisika baru atau situasi fisika yang dinyatakan dalam bentuk deskriptif. Mahasiswa masih sering menyelesaikan persoalan momentum yang dinyatakan secara deskriptif, tidak dalam bentuk angka-angka, tanpa menggunakan prinsip Fisika yang telah dipelajari. Kedua, mahasiswa memandang konsep momentum sama dengan konsep energi, yaitu sebagai besaran skalar.Ketiga, mahasiswa kesulitan menerapkan hukum kekealan momentum dalam situasi fisika baru, terutama dalam konteks soal yang memiliki massayang berubah. Mahasiswa terlalu fokus pada aspek kecepatan dalam penyelesaian persoalan momentum. Keempat, adanya kekeliruan berpikir terkait keberlakuan hukum kekekalan momentum untuk benda, bukan hanya untuk sistem. Kelima, mahasiswa kesulitan dalam mendeskripsikan momentum, perubahan momentum, impuls yang dinyatakan dalam representasi vektor. 


\section{UCAPAN TERIMAKASIH}

Terimakasih kepada semua pihak yang telah banyak membantu dalam penelitian ini, terutama mahasiswa jurusan pendidikan Fisika angkatan 2014 yang mengontrak mata kuliah Fisika Dasar 1 Universitas Pendidikan Indonesia dan yang telah banyak memberikan kontribusi pada penelitian ini.

\section{REFERENSI}

Close, H.G., Heron, P.R.L. 2010 'Research as guide for improving student learning: An example from momentum conservatio' Am. J. Phys. 78(9), p. 961-969.

Graham, T., Berry, J. 1996, ' A hierarchical model of the development of student of understanding of momentum’ Int. J. Sci. Educ. 18(1), p. 75-89.

Gronlund. 1985, 'Menyusun Hasil Belajar', Semarang, IKIP Semarang Press.

Heron, P.R.L., McDermott, L.C. 1998, ' Bridging the gap. Between teaching and learning in geometrical optics', Optics \& Photonics News, Sept. p. 30-36.

Hestenes, D., Wells, M. 1992, 'A mechanics baseline test' Phys. Teach. 30(), p. 159-166.

Lawson, R.A., McDermott, L.C. 1987, 'Student understanding of the work-energy and impulsemomentum theorems', Am. J. Phys. 55(9). (), p. 811-817.

McDermott, L.C. 2013, 'Improving the teaching of science through discipline-based education research : An example from physics' . Eur. J. Sci. Math. Ed.1(1), p. 1-12.

Mulyono, A. 2003, 'Pendidikan Bagi Anak Berkesulitan Belajar', Jakarta, Rineka Cipta.

Pride, T.O., Vokos, S., McDermott, L.C. 1998, 'The challenge of matching learning assessments to teaching goals: An example from the work-energy and the impulse-momentum theorems' . Am. J. Phys. 66(2)., p. 147-157.

Singh, C.,Rosengrant, D. 2003, 'Multiple-choice test of energy and momentum concepts', Am. J.Phys. 71(6). p. 607-617.

Surya, M.,Amin, M. 1984, 'Pengajaran Remidial', Jakarta, Depdikbud.

Van Heuvelen, A. 1991, 'Overview Case StudyPhysics' Am. J. Phys.59(10), p. 898-907. 